\title{
OCCURRENCE OF MICROORGANISMS AND AFLATOXINS IN ARTISANAL PUBA FLOUR IN TOCANTINS, BRAZIL
}

Ocorrência de micro-organismos e aflatoxinas em farinha de puba artesanal produzida no Tocantins, Brasil

Ocurrencia de microorganismos y aflatoxinas em la harina de la puba hechas a mano producidos en Tocantins, Brasil
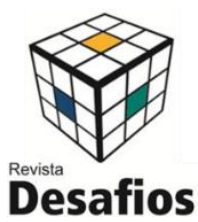

Artigo Original

Original Article

Artículo Original

Luana Martins Coelho ${ }^{* 1}$, Francisca Maria Pinheiro de Sousa ${ }^{1}$, Paula Benevides de Morais ${ }^{1}$, Guilherme Prado ${ }^{2}$, Juliana Fonseca Moreira da Silva and Raphael Sanzio Pimenta ${ }^{* 1}$

${ }^{1}$ Laboratório de Microbiologia Ambiental e Biotecnologia, Universidade Federal do Tocantins - UFT, Palmas TO, Brasil.

${ }^{2}$ Fundação Ezequiel Dias - FUNED, Belo Horizonte - MG, Brasil.

*Correspondência: Laboratório de Microbiologia Ambiental - UFT, Av NS 15, Bloco II sala 05, Palmas - TO.

CEP: 77.020-210. Caixa postal 114.Fonelfax: (63) 3232-8007.Email: pimentars@uft.edu.br.

Artigo recebido em 23/08/2016. Aprovado em 10/10/2016. Publicado em 25/10/2016.

\begin{abstract}
This work aimed to characterize the microbiota involved in the production of puba flour in Palmas, Brazil, and to verify the presence of aflatoxins in this food product. Counts of mesophilic heterotrophic bacteria, Lactobacillus spp., Streptococcus spp. and yeasts were done by dilution and plating on specific media. The results showed the presence of high populations of all microbial groups screened $\left(>10^{7} \mathrm{CFU} \mathrm{\textrm {g } ^ { - 1 }}\right)$. Among lactobacilli, L. plantarum was the most frequent species, representing $41.6 \%$ of total isolates of this genus. The most frequent yeasts were Candida castelli, C. ethanolica, C. krusei, Pichia membranifaciens and Trichosporon asahii. Counts of total and fecal coliforms obtained by the chromogenic Colilert technique were high mainly in samples of fermenting water, above 800 and 2,000 MPN $100 \mathrm{~mL}^{-1}$ respectively. Nevertheless in the final product those numbers were reduced considerably to less than 70 and $1 \mathrm{MPN} \mathrm{g}^{-1}$ respectively, values considered within the legal limits established by regulations. ELISA and thin layer chromatography showed no occurrence of aflatoxins, differently from other studies elsewhere. With this we can to observe that the products analyzed fit the Standards of the Brazilian Ministry of Health.
\end{abstract}

Keywords: Manihot esculenta Crantz, microorganisms, aflatoxin.

\section{RESUMO}

O objetivo foi caracterizar a microbiota envolvida na produção de farinha de puba em Palmas, Brasil, e verificar a presença de aflatoxinas neste produto alimentar. Contagens de bactérias heterotróficas mesófilas, como Lactobacillus spp., Streptococcus spp. e leveduras foram realizadas por diluição e plaqueamento em meios específicos. Os resultados mostraram a presença de elevados números populacionais de todos os grupos microbianos pesquisados (> $10^{7} \mathrm{UFC} \mathrm{g}^{-1}$ ). Entre os lactobacilos, L. plantarum foi a espécie mais frequente, representando 41,6\% dos isolados totais deste gênero. As leveduras mais frequentes foram Candida castelli, $C$. ethanolica, C. krusei, Pichia membranifaciens e Trichosporonasahii. As contagens de coliformes totais e fecais obtidas pela técnica Colilertcromogénico foram elevadas, principalmente em amostras de água de fermentação, 
acima de 800 e $2000 \mathrm{NMP} 100 \mathrm{~mL}^{-1}$, respectivamente. No entanto, no produto final esses números foram reduzidos consideravelmente a menos de 70 e $1 \mathrm{MPN} \mathrm{g}^{-1}$, respectivamente, valores considerados dentro dos limites estabelecidos pelos regulamentos. Não foi observada presença de aflatoxinas em nenhum dos testes realizados (ELISA e cromatografia em camada delgada), resultados divergentes de outros estudos realizados em outros países. Com isto pode se concluir que os produtos analisados atendem às normas do Ministério da Saúde do Brasil.

Palavras-chave: Manihot esculenta Crantz, micro-organismos, aflatoxina.

\section{RESUMEN}

El objetivo fue caracterizar la microbiota involucrada en la producción de harina en Palmas, Brasil, verificando la presencia de aflatoxinas. Se realizaron conteos mediante dilución y plaqueamiento en medios específicos de bacterias heterotróficas mesófilas, como Lactobacillus spp., Streptococcus spp. y levaduras. Los resultados indicaron la presencia de un elevado número poblacional de todos los grupos microbianos estudiados (> $10^{7}$ UFC $\left.\mathrm{g}^{-1}\right)$. Entre los lactobacilos, L. plantarum fue la especie más frecuente, representada por $41,6 \%$ de los aislados totales de este género. Las levaduras más representativas fueron Candidacastelli, C. ethanolica, C. krusei, Pichiamembranifaciens y Trichosporon asahii. Los conteos de coliformes totales y fecales obtenidos por la técnica de Colilertcromogénico fueron elevados, principalmente en muestras de agua, superando los 800 a 2000 NMP 100 $m L^{-1}$, respectivamente. Sin embargo, en el produto final, estos porcentajes se redujeron considerablemente a menos de 70 y 1 MPN $g^{-1}$, respectivamente. Estos valores son considerados dentro de los límites establecidos por reglamentos. No se observó la presencia de aflatoxinas en ninguno de los ensayos (ELISA y cromatografía en capa delgada). Los resultados fueron diferentes a otros estudios realizados en otros países; concluyendo que los productos analizados cumplen las normas del Ministerio de Salud de Brasil.

Descriptores: Manihot esculenta Crantz, microorganismos, aflatoxina.

\section{INTRODUCTION}

Contamination of flours has been objective of various studies, but in general those works only investigate the size of fungal populations in the product. The characterization of the microbial community is rare (WEIDENBORNER et al., 2000). Puba flour is a product of grinded fermented cassava (Manihot esculenta Crantz) roots, extensively used in Brazilian culinary, mainly in the states of North and Northeast regions. The roots are immersed in water for 12 to $48 \mathrm{~h}$, usually $24 \mathrm{~h}$, than grinded and dried by pressing and taken to large sun-bathed surfaces or to open ovens to complete drying. The flour may be consumed in natura, or as a substitutive for wheat in the production of pasta, cakes and pies (PAIVA, 1991).
The production of puba flour includes a fermentation stage with the contribution of various microorganisms naturally inoculated that improves the taste, increases durability and reduces toxicity of cyanidric acid present in the cassava and also aggregates economic value to cassava (MENEZES et $a l .$, 1998). The preference for the more acid flavor of flour may be related to consumer habits of such differentiated product that choose to acquire flour water for presenting said flavor "more acidic," the resulting fermentation time superior to 48 hours (SILVA et al., 2012). It is characterized by having high value energy due to the high concentration of carbohydrates, and contains fiber and some minerals such as calcium, iron, phosphorus, sodium and potassium (SANTOS et al., 2012). 
Puba flour is produced artisanally in Flour Houses by small producers, both individually or in cooperatives, presenting no uniformity and low hygiene standards that lead to interference with the quality of final product (FARIAS et al., 2005). These conditions may also interfere with the establishment of the microbiota that is responsible for the fermentation of cassava and may favor contamination of the product with undesirable microorganisms such as pathogenic bacteria and aflatoxin-producing fungi. Our objective was to identify the microbiota involved in the fermentation process for puba flour production in two small-scale plants in the Palmas region of Tocantins state, Brazil and also to detect the presence of aflatoxins in the final product.

\section{MATERIAL AND METHODS}

The work used two approaches, the first one being the characterization of the microbiota of the process of production of puba flour in two different Flour Houses (the production plants) run by individual producers, and the second one being the characterization and quantification of aflatoxins in random samples of ready-to-use puba flour obtained from markets in Palmas, Tocantins, Brazil.

For the first approach, samples that included three replicates of fermented cassava mass and puba flour recently produced and ready for commercialization were collected in the two different Flour Houses in the rural area of Palmas city. An individual sample was obtained from each of six different lots/batches at fifteen days intervals in each Flour House from February to April, 2007. Each sample was serially diluted $\left(10^{-1}, 10^{-3}\right.$ and $\left.10^{-6}\right)$ and aliquots used for inoculation in the different media. Counts of heterotrophic mesophillic bacteria were done by inoculating $0.1 \mathrm{~mL}$ aliquots of each dilution on PCA (triptone $0.5 \%$, yeast extract $0.25 \%$, dextrose $0.1 \%$, agar $1.5 \%$ ) by the pour-plate technique that were incubated at $37{ }^{\circ} \mathrm{C}$ for $48 \mathrm{~h}$ (SIQUEIRA, 1995). Isolation of lactic acid bacteria was done by pour-plating aliquots of $0.1 \mathrm{~mL}$ of the same dilutions on Man, Rogosa and Sharpe (MRS) Agar for isolation of Lactobacillus and M17 Agar for Streptococcus. Plates were incubated at $37{ }^{\circ} \mathrm{C}$ for 72 $\mathrm{h}$, colonies counted and purified on the same media described above (LACERDA et al., 2005). Pure cultures were submitted to Gram staining and catalase reaction test. For Lactobacillus species differentiation, the method of carbohydrate utilization proposed by RAIBAUD et al. (1973) was used. Yeast isolation was done by plating aliquots of $0.1 \mathrm{~mL}$ of the same dilutions on YM agar (Yeast extract $0.3 \%$; malt extract $0.3 \%$; peptone $0.5 \%$; glucose $1 \%$; agar $2 \%$ ) added with chloramphenicol $100 \mathrm{mg} / \mathrm{L}$, incubated at $25^{\circ} \mathrm{C}$ for $48 \mathrm{~h}$. Yeasts were counted, purified and identified by the standard procedures and taxonomic keys of KURTZMAN et al (2011). Results were expressed as the average Colony Forming Units (CFU) for each microbial type per sample (cassava mass and puba flour).

The investigation also included the counts of coliform bacteria in the water used for immersion of cassava roots (source water), in the fermenting cassava water and in the ready-for-use puba flour samples in both Flour Houses cited above. Three replicates of each sample were inoculated on ColiLertQuanti-Tray (IDEXX Laboratories, Inc. Wetsbook ME) (Eaton et al., 2005). Results were expressed as the Most Probable Number (MPN) of coliforms per $100 \mathrm{~mL}$ of liquid sample or per gram of solid sample (ALVES et al., 2002).

The second approach comprised the detection of aflatoxins in 50 puba flour samples from different Flour Houses, obtained in different distribution points in Palmas. Samples were analyzed by two technics: 
Enzyme Linked Immunosorbent Assay (ELISA Agri-Screen - NEOGEN Corporation) and thin layer chromatography (TLC) according Valente Soares and Rodrigue-Amaya (1989). In this methodology a 300 $\mathrm{mL}$ a mixture of methanol-KCl (4\%) (270:30) was added to the sample and shaken for $30 \mathrm{~min}$. One hundred and fifty milliliters of the filtered extract was added with $150 \mathrm{~mL} 10 \%$ cupric sulfate. After filtration, $150 \mathrm{~mL}$ of filtrate was added to $150 \mathrm{~mL}$ water contained in a separatory funnel and extracted twice with $10 \mathrm{~mL}$ chloroform. The chloroformic phase was evaporated to dryness under a gentle stream of nitrogen. The dry extract was dissolved $(200 \mu \mathrm{L})$ in benzene-acetonitrile (98:2) and 2 to 10 $\mu \mathrm{L}$ were spotted on thin layer chromatography (TLC) plates, 20 by $20 \mathrm{~cm}$. Extracts were separated by development of TLC aluminium sheet which precoated with silica gel 60 (E. Merck, Darmstadt, F. G. R.) with a mixture of toluene-ethyl acetatechloroform-formic acid (70:50:50:20, v/v/v/v), and quantified by fluorodensitometry at $365 \mathrm{~nm}$ using a Shimadzu CS9301 fluorodensitometer (Shimadzu Corp., Kyoto, Japan). The aflatoxins concentration was determined by comparing the fluorescent intensity of sample spots with known amounts of standard spotted on the same plate. The detection limit was $0.9 \mu \mathrm{g} \mathrm{kg}^{-1}$.

\section{RESULTS AND DISCUSION}

Results from the fermented cassava mass (Table 1) showed elevated counts for heterotrophic mesophilic bacteria (above $10^{8} \mathrm{CFU} \mathrm{g}{ }^{-1}$ ), lactobacilli

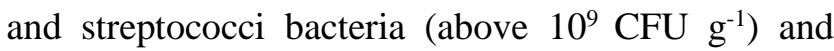
yeasts (above $10^{7} \mathrm{CFU} \mathrm{g}{ }^{-1}$ ). These counts are expected since the cassava fermentation presents favorable environmental and nutritional conditions for the development of microorganisms. Artisanal cassava fermentations are usually done by adding untreated water to the cassava roots in closed recipients or by immersion of the roots in natural water courses. The microbiological contamination may occur at all stages by passing agricultural products, from harvesting to processing, packaging, transportation, storage and various physical contact, mechanical or manual. However, microbial growth depends upon the type of substrate that constitutes the food, or the biological development conditions that the product features, particularly relating to water availability, required metabolic processes (NETO et al., 2004).

The high water activity and presence of nutrients from the roots favor the growth of different microorganisms. Afterwards microbial metabolism alters the environmental characteristics that lead to a change in the community composition. According to FIGUEROA et al. (1995), traditionally the cassava fermentation presents an ecological succession. AMPE et al. (2001) suggest that this succession is determined by the elimination of species sensitive to the acid environment generated by the fermentation. In the present work, the high populations of Lactobacillus spp. and Streptococcus spp. (both above $10^{9} \mathrm{CFU} \mathrm{\textrm {g } ^ { - 1 }}$ ) corroborate this information, since both genera can easily grow in low $\mathrm{pH}$, the prevailing condition at the end of the process. The high yeast counts were also favored by acid environment of the process. It has been suggested that the development of yeasts in fermented foods can be favored by the acidic environment created by bacteria and that the growth of bacteria is stimulated by the presence of yeasts, which may provide growth factors (SCHWAN et al., 2007). The production of acids and other antimicrobial components during fermentation may promote or improve the microbiological safety and stability of the product. 
Table 01: Average counts of microorganisms in the cassava mass submitted to fermentation for puba flour production in two Flour Houses in Palmas, Tocantins $\left(\mathrm{CFU} \mathrm{g}^{-1}\right)$.

\begin{tabular}{lcc}
\multicolumn{1}{c}{ Microorganisms } & Flour House 1 & Flour House 2 \\
\hline Heterotrophic mesophilic bacteria & $4.1 \times 10^{8}$ & $4.2 \times 10^{8}$ \\
Lactobacillus spp. & $2.8 \times 10^{9}$ & $1.2 \times 10^{9}$ \\
Streptococcus spp. & $2.4 \times 10^{9}$ & $1.0 \times 10^{9}$ \\
Yeasts & $1.0 \times 10^{7}$ & $1.8 \times 10^{7}$ \\
\hline
\end{tabular}

Samples of ready-for-use puba flour presented an average count of $7.8 \times 10^{4} \mathrm{CFU} / \mathrm{g}$ of heterotrophic mesophillic bacteria, $3.2 \times 10^{8} \mathrm{CFU} \mathrm{g}^{-1}$ of Lactobacillus spp., $2.9 \times 10^{7} \mathrm{CFU} \quad \mathrm{g}^{-1}$ of Streptococcus spp. and $1.0 \times 10^{4} \mathrm{CFU} \mathrm{g}^{-1}$ of yeasts. A factor that may help to explain the apparent reduction of microbial counts in the puba flour is that contrary to what is observed in the initial stages of the process, the final stages of production include drying and roasting (PAIVA, 1991) that lowers water activity and improves the hygiene of the final product.

Nevertheless, these counts can be considered high due to low water activity of the flour and apparent loss of easily available nutrients by the drying process. Lactic acid bacteria usually grow in low water content foods (OYEWOLE, 1992). Yeasts are not usually found in substrates with low sugar content (FLEET, 2011), since the counts above $10^{4}$ $\mathrm{CFU}^{-1}$ can be considered high. According to NETO et al. (2004) and CEREDA (1973), high counts of heterotrophic mesophillic bacteria indicate improper conditions such as contaminated raw materials, unfavorable environmental conditions and also it indicates potential for the development of pathogens.

Coliform counts were also high in the liquid samples, the source water and the fermenting water, reflecting the low sanitary conditions of the process (Table 02). The difference found between initial counts in samples from the two Flour Houses is due to the use of well water by House 1 whereas House 2 uses treated water. Counts rise during the fermentation process in both Houses, indicating that contamination occurs during this stage that usually takes 24-h in open vessels subject to contact with insects, birds and domestic animals in the yard of the Flour House, together with the manipulation by the producers during the whole process.

Table 02: Average counts of coliform bacteria in the water samples from the production process of puba flour in two Flour Houses in Palmas, Tocantins (MPN $100 \mathrm{~mL}^{-1}$ ).

\begin{tabular}{llccc}
\hline & \multicolumn{2}{c}{ Flour House 1 } & \multicolumn{2}{c}{ Flour House 2 } \\
\cline { 2 - 5 } Coliform & Source water & Fermenting water & Source water & Fermenting water \\
\hline Total & 282.9 & $\geq 2,419.6$ & 9.9 & $2,150.7$ \\
Fecal & 90.6 & $1,373.1$ & $\leq 1$ & 877.1
\end{tabular}

The coliform counts in the final product were low, on average 69.1 MPN g ${ }^{-1}$ of total coliforms in
Flour House 1 samples and 13.5 MPN g ${ }^{-1}$ in Flour House 2 samples. Fecal coliform numbers were 1 MPN g-1 in Flour House 1 samples and 4.1 $\mathrm{MPN} \mathrm{g}^{-1}$ 
in Flour House 2 samples. These numbers are according to the Brazilian standards established by Resolution RDC n ${ }^{\circ} 12$ of 02.01.2001 from National Agency for Sanitary Surveillance that proposes maximum values of $10^{2} \mathrm{MPN} \mathrm{g}^{-1}$ for total coliforms and $10 \mathrm{MPN} \mathrm{g}^{-1}$ for fecal coliforms (BRASIL, 2001). Similar results were found by NETO et al. (2004) and LACERDA et al. (2005), in cassava flour obtained in process traditional, in researches on the microbial communities of cassava flour, spicy cassava flour and starch flour. Probably the process of drying and roasting of the flour promotes the reduction of microbial populations. The group of coliforms includes four genera, Escherichia, Enterobacter, Citrobacter and Klebsiella, of which the last three, are not mandatory fecal origin. E. coli more representative indicator of contamination fecal is presumed that a bacterium contamination caused by rodents during storage of foods (SILVA et al., 2012). The presence of coliforms in food can indicate the presence of a wide variety of enteric pathogens (RAMOA-JUNIOR et al., 2005). The presence of coliform microorganisms is considered an indicator of poor conditions in the production and / or food handling. The high number of coliforms does not mean direct contamination with fecal material, but lack of technique in handling, such as handler hygiene, inadequate transport and packaging (CHISTÉ et al. 2007).

The characterization of the lactic acid bacteria included the identification of sixty different isolates of the genus Lactobacillus obtained on MRS. Lactobacillus species were mostly from the homofermentative group: L. acidophilus (5.0\%), L. casei (3.3\%), L. casei subsp. Pseudoplantarum (5.0 $\%)$, L. casei subsp.tolerans (3.3\%), L. coryniformis subsp. coryniformis $(11.7 \%)$; L. delbrueckii $(1.7 \%)$, L. leichmanii (1.7\%), L. plantarum (41.7\%) and L. salivarius (3.3\%). Among those, L. acidophilus and L. plantarum are known as probiotic and may be inoculated in flour products for use as animal feed (TEIXEIRA et al., 2003). Among the heterofermentative species L. brevis $(3.3 \%), L$. fermentum (16.7\%) and L. fructivorans (3.3\%) were found. Some of these species were already obtained in other studies on the cassava for starch and food production in Latin America and Africa (LACERDA et al., 2005; KOSTINEK et al., 2005; COULIN et al., 2006).

The yeasts comprised 60 isolates belonging to 17 species among which Candida castelli, $C$. ethanolica C. krusei, Pichia membranifaciens and Trichosporon asahii were frequent. One species from the genus Saccharomyces, S. unisporus, was also isolated from one sample (Table 03).

Table 03- Frequency of occurrence of yeasts in samples of fermented cassava.

\begin{tabular}{lc}
\hline \multicolumn{1}{c}{ Yeast species } & Frequency of occurrence \\
\hline Bullera megalospora & 02 \\
Blastobotrys elegans & 01 \\
Candida albicans & 01 \\
C. bombii & 01 \\
C. castelli & 13 \\
C. ethanolica & 10 \\
C. krusei & 08 \\
C. parapilosis & 01 \\
C. petrohuensis & 01 \\
Cryptococcus consortiums & 01 \\
Cryptococcus huempii & 02 \\
Dipodacus ambrosiae & 01 \\
Dipodascus ovetensis & 01 \\
Pichia membranifaciens & Saccharomyces unisporus
\end{tabular}


Sporidiobolus salmonicolor

01

Trichosporon asahii

07

Total

60

Analized the microbial communities of Attiéké, COULIN et al. (2006), a food product from fermented cassava in in the south of Côte d'Ivoire (Abidjan region, Switzerland) and observed the presence of only three yeast species: Saccharomyces cerevisiae, C. tropicalis and C. krusei. Among these the only species isolated in our study was C. krusei. Another study on the fermentation of cassava and rice for beverage production in Northern Brazil showed the presence of seven yeast species, among which $C$. parapsilosis and Trichosporon asahii were dominant (SCHWAN et al., 2007).Yeasts are frequently isolated from fermented substrates rich in starch, and many of them present amilolytic activity. Among the species isolated in this work, only four: $B$. megalospora, B. elegans, C. albicans and C. huempii presented amilolytic activity. It is possible that the non-amilolytic yeasts grow on soluble sugars derived from starch degradation by bacteria and these yeasts. Their growth may be favored by the low $\mathrm{pH}$ produced by the activity of other microorganisms involved in the fermentation. Only six yeast species were strong fermenters, among which $C$. castelli, the most frequent yeast in fermented cassava mass. Three species were slow fermenters, including the high frequent $C$. ethanolica and $P$. membranifaciens, whereas eight species that included the frequent yeast T. asahii were non-fermentative.

In this study, $19 \%$ of the species have been identified as belonging to the genus Candida. Among these species have been found as opportunistic known as $C$. albicans and C. glabrata (KURTZMAN et al., 2011). The species C. albicans is an opportunistic pathogen present in the feces, however, can be found in natural waters (MEDEIROS et al., 2008). Candida glabrata, C. parapsilosis and C. krusei have been reported as etiologic agents of candidiasis (KURTZMAN et al., 2011). The frequent yeast Candida castelli specie, initially was found to resemble $C$. glabrata, but differed in fermentation properties.

Tests for detection of aflatoxins $B_{1}, B_{2}, G_{1}$ e $G_{2}$ in the fifty samples resulted with no or low content of aflatoxins $\left(\leq 1,0 \mu \mathrm{g} \mathrm{kg} \mathrm{kg}^{-1}\right)$ below the limits of the Brazilian Ministry of Health standards established by Resolution 34/CNNPA (BRASIL, 1976) as maximum tolerance of $30 \mathrm{ppb}\left(30 \mu \mathrm{g} \mathrm{kg}^{-1}\right)$ of aflatoxins $\mathrm{B}_{1}$ and $\mathrm{G}_{1}$. In Brazil few works present the incidence of mycotoxins in cassava flour. EIROA and ARCKOL (1978) did not detect aflatoxins, patulin or esterigmatocistin in samples of different flour types in Campinas (São Paulo). Also VALENTE SOARES and RODRIGUEZ-AMAYA (1989) analyzed three different cassava flour types commercialized in Campinas, São Paulo State from May, 1985 to June, 1986 and did not isolate aflatoxinas, ocratoxin zearalenone and esterigmatocistin. CATÃO (1999) evaluated the fungal microbiota and presence of aflatoxins in 18 samples of cassava flour from the street markets and supermarkets in João Pessoa (PB) that resulted in the isolation of Aspergillus flavus from $50 \%$ of the samples and detection of aflatoxins in two samples. In Nigeria, IBEH et al. (1991) detected aflatoxins $\mathrm{B}_{1}$ e $\mathrm{G}_{1}$ values from 1.5 to $5.5 \mu \mathrm{g}$ $\mathrm{kg}^{-1}$ in four among ten samples of cassava flour.

Comparing the cassava flour production in traditional units and model units, DÓSEA et al (2010), found a decrease in microbial count of $82.7 \%$ in the dough pressed into traditional units models relative units, suggesting that the action of manipulators and the sanitary conditions of the equipment are responsible 
for the incidence of these microorganisms processing of cassava.

\section{CONCLUSION}

Cassava fermentation for the production of puba flour occurs mainly due to the activity of lactic acid bacteria specially Lactobacillus together with yeasts. Although undesirable bacteria such as coliforms are found, these microbial counts are lowered to acceptable numbers by the end of the process mainly due to the raise in acidity during the fermentation stage and to exposition to high temperatures. With this we can to observe that the products analyzed fit the Standards of the Brazilian Ministry of Health.

\section{AKNOWLEDGEMENTS}

This work was funded by the Conselho Nacional de Desenvolvimento Científico e Tecnológico of Brasil, and Conselho Estadual de Ciência e Tecnologia do Tocantins PROCESS 2007 $2029 \mathrm{PPP} / \mathrm{SECT} / \mathrm{CECT} / \mathrm{MCT} / \mathrm{CNPq} / \mathrm{CT}-\mathrm{INFRA} \mathrm{N}^{\circ}$ 01/2006. The authors thank Cristiane Martins Coelho for her technical assistance.

Todos os autores declararam não haver qualquer potencial conflito de interesses referente a este artigo.

\section{REFERENCES}

ALVES, N. C.; ODORIZZI, A. C.; GOULART, F. C. 2002. Análise microbiológica de águas minerais e de água potável de abastecimento, Marília, SP. Revista Saúde Pública, p. 749-751, 2001.

AMPE, F.; SIRVENT, A.; ZAKHIA, N. Dynamics of the microbial community responsible for traditional sour cassava starch fermentation studied by denaturing gradient gel electrophoresis and quantitative rRNA hybridization. Int.Jour. of Food Microbiology,65, 45- 54, 2001.
BRASIL. Ministério da Saúde. Resolução RDC no 12 , da ANVISA, de 02 de janeiro de 2001. Diário Oficial da União, 03 de janeiro de 2001.

BRASIL. Ministério da Saúde. Resolução RDC n ${ }^{\circ}$, da ANVISA, de 1976. Diário Oficial da União, 1976.

CATÃO, M.N.S. Isolamento de fungos contaminantes e aflatoxigênicos na farinha de mandioca (Manihot esculenta Crantz). João Pessoa, PB. Dissertação (Mestre em Ciência e Tecnologia de Alimentos), Universidade Federal da Paraíba. 56 p, 1999.

CEREDA, M. P. Alguns Aspectos sobre a Fermentação da Fécula de Mandioca. Botucatu. Tese (Mestrado em Ciência dos Alimentos) Faculdade de Ciências Médicas e Biológicas, Universidade do Estado de São Paulo (UNESP). $89 \mathrm{p}, 1973$.

CHISTÉ, R. C.; COHEN, K. O.; MATHIAS, E. A.; RAMOA JÚNIOR, A. G. A.Estudo das propriedades físico-químicas e microbiológicas no processamento da farinha de mandioca do grupo d'água. Ciên.eTecnol. de Alimentos, Campinas, v. 27, n. 2, p. 787- 792,2007.

COULIN, P., FARAH, Z., ASSANVO, J., SPILLMANN, H., PUHAN, Z. Characterisation of the microflora of attiéké, a fermented cassava product, during traditional small-scale preparation. Int.Jour. of Food Microbiology, v. 106. p.131136,2006 .

EATON, A. D., CLESCERI, L. S., RICE, E. W., GREENBERG, A. E. (ED.) Standart methods for the examination of water and wastewater. Am. Pub.Health Association. 21st Ed. Washington, DC. APHA, 9-72 - 9-74, 2005.

DÓSEA, R.R.; MARCELLINI, P.S.; SANTOS, A.A.; RAMOS, A.L.D.; LIMA, A.S. Qualidade microbiológica na obtenção de farinha e fécula de mandioca em unidades tradicionais e modelo. Ciência Rural, v.40, n.2,2010.

EIROA, M. N. U.; ARCKOL, D. B. Investigação de aflatoxinas, patulina, e esterigmatocictina em amostras de diversos tipos de farinhas. Bol. Inst. Tecnol. Alimentos, Campinas, v.57, p. 113-121, 1978.

FARIAS, A. R. N.; MATSUURA, F. C. A. U.; FOLEGATTI, M. I. S.; CARDOSO, E. M. R.; 
CANTO, A. C. Proc. e Util. da Mandioca, Embrapa,2005.

FIGUEROA, C.; DAVILA, A.M.; POURQUIÉ, J. Lactic acid bactéria of the sour cassava starch fermentation. Let.in Appl. Microbiology,21, 126130,1995 .

FLEET, G.H.. Yeasts spoilage of foods and beverages. In: Kurtzman, C.P.; Fell, J.W.; Boekhout, $\mathrm{T}$ (Ed.). The Yeasts: a taxonomic study. $5^{\text {th }}$ edition. Elsevier, 2011. V.1 Cap.5 pp 53-63,2011.

IBEH, I. N.; URAIH, N.; OGONOR, J. I. Dietary exposure to aflatoxin in Benin City, Nigeria: a possible public heath concern. Int.Jour. of Food Microbiology, v. 14, p. 171-174, 1991.

KOSTINEK, M, SPECHT, I., EDWARD, V.A., SCHILLINGER, U., HERTEL, C., HOLZAPFEL, W.H., FRANZ, C.M.A.P. Diversity and technological properties of predominant lactic acid bacteria from fermented cassava used for the preparation of Gari, a traditional African food. Syst. and App. Microbiology,v.28, p. 527-540,2005.

KURTZMAN, C.P.; FELL, J.W.; BOEKHOUT, T (Ed.). 2011. The Yeasts: a taxonomic study. $5^{\text {th }}$ edition. Elsevier.

LACERDA, I. C. A. MIRANDA R.L., BORELLI, B.M., NUNESA.C., NARDI, R.M.D., LACHANCE, M.A., ROSA, C.A. Lactic acid bacteria and yeasts associated with spontaneous fermentations during the production of sour cassava starch in Brazil. Int.Jour. of Food Microbiology, v.16, p. 213-219,2005.

MENEZES, T. J. B.; SARMENTO, S. B. S.; DAIUTO, É. R. Influência de Enzimas de Maceração na Produção de Puba. Ciência, Tecnol. e Alimentos, p. 386-390,1998.

NETO, C.F., NASCIMENTO, E.M., FIGUEIREDO, R.M., QUEIROZ, A.J.M. Microbiologia de farinhas de mandioca (Manihot esculenta Crantz) durante o armazenamento. Ciência Rural, v.34, p. 551555,2004 .

OYEWOLE, O.B. Cassava processing in Africa. In: Appl. of Biotec.toTrad.Ferm. Foods. BOSTID, pp. 89-92. National Research Council, USA, 1992.

PAIVA, F. F. A. Controle de qualidade da farinha de mandioca (Manihot esculenta Crantz) produzida na região metropolitana de Fortaleza. Fortaleza, CE.
Dissertação (Mestre em Tecnologia de Alimentos), Universidade Federal do Ceará (UFCE). 216 p,1991.

RAIBAUD, P., GALPIN, J.V., DUCLUZEAU, R, MOCQUOT, F., OLIVER, G. The "Lactobacillus" genus in the digestive tract of rats. I. Characteristics of homofermentative strains isolated from holo- and gnotoxenic rats. Annales de Microbiologie, v. 124, p. 83-109,1973.

RAMOA JÚNIOR, A. G. A.; COHEN, K. O.; MATHIAS, E. A.; CHISTÉ, R. C.; LIMA, C. L. S. Avaliação Microbiológica das farinhas de mandiocas do grupo seca comercializadas na Cidade de Belém. In: Anais do VI SLACA-Simpósio Latino Americano de Ciência de Alimentos. CD-ROM. Campinas/São Paulo, 2005.

SANTOS, T.T.; SOUZA, E.X.N.; SILVA, L.C.; CAZETTA, M. L. Avaliação Avaliação microbiológica e físico-química da farinha de mandioca comercializada no mercado municipal de Cruz das Almas - BA. Magistra, v. 24, n. 1, p. 3441, 2012.

SCHWAN, R.F., ALMEIDA, E.G., SOUZA-DIAS, M.A.G., JESPERSEN, L. Yeast diversity in ricecassava fermentations produced by the indigenous Tapirapé people of Brazil. FEMS Yeast Research, v.7. p. 966-972, 2007.

SILVA, J.T.S.; CARVALHO, J.S.; VALE, V.L.C. Estudo das condições microbiológicas de farinhas de mandioca (Manihot esculenta Crantz) comercializadas no centro de abastecimento de Alagoinhas, Bahia. Semina: Ciências Biológicas e da Saúde, Londrina. v 33, n.1, p 43-52, 2012.

TEIXEIRA, A.S., CAVALCANTI, J.S., OST, P.R., SCHOULTEN, N.A. Probióticos em rações para frangos de corte utilizando farinha de carne e ossos com diferentes níveis de contaminação bacteriana.Ciências Agrotecnológica, Lavras. v.27, n.4, p.927-933,2003.

VALENTE SOARES, L. M.; RODRIGUEZAMAYA, D. B. Survey of aflatoxins, ochratoxins A, zearalenone, and sterigmatoystin in some brazilian foods by using multi-toxin thin-layer chromatographic method. Jour. Assoc.Offic.and Anal. Chemists, Washington, v. 72, n. 1, p. 2225,1989 .

WEIDENBORNER, M., WIECZOREK, C., APPEL, S., AND KUNZ, B. Whole wheat and white wheat flour - the mycobiota and potential mycotoxins. FoodMicrobiology,v.17, p. 103-107,2000. 
